\title{
"Contamination Assessment of Abandoned Mines by Integrated Pollution Index in the Han River Watershed"
}

\author{
Hosik Lee ${ }^{*}, 1$, Md. Imran Kabir ${ }^{1}$, Phil Sang Kwon ${ }_{3}^{1}$, Jong Myeong Kim ${ }^{1}$, Jeong Gyu Kim ${ }^{2}$, Seung \\ Hun Hyun ${ }^{2}$, Yeon Taek Rim ${ }^{3}$, Myoung Soon Bae ${ }^{3}$, Eul Ryul Ryu ${ }^{3}$ and Myung Sook Jung \\ ${ }^{1}$ Department of Environmental Engineering, Chungju National University, Daehak-ro 72, Chungju-si, Chungbuk, 380- \\ 702, Korea \\ ${ }^{2}$ Graduate School of Life and Environmental Sciences, Korea University, Anam-dong, Seongbuk-gu, Seoul, 136-713, \\ Korea \\ ${ }^{3}$ Department of Welfare \& Environmental Research, Chungbuk Development Institute, Bookmun-ro, 1ga Sangdang-gu, \\ Cheongju, Chungbuk, 360-011, Korea \\ ${ }^{4}$ National Institute of Environmental Research, Han-River Environment Research Laboratory, 627 Yangsu-ri, Yangseo- \\ myeon, Yangpyeong-kun, Kyounggi, 476-823, Korea
}

\begin{abstract}
Heavy metal contamination from abandoned mine areas is a major threat for the environment. The study objective was to categorize the most polluted mine areas among 44 mine sites at the four cities of Chungcheongbuk-do province in South Korea. Both water and soil samples were collected from the mine area. The $\mathrm{pH}$ of the water and soil ranged from 3.6 to 8.5 and from 4.1 to 9.1 respectively. A significant amount of arsenic (As), cadmium (Cd), copper $(\mathrm{Cu})$, nickel $(\mathrm{Ni})$, lead $(\mathrm{Pb})$, zinc $(\mathrm{Zn})$ and mercury $(\mathrm{Hg})$ occurred in soil samples collected from the mine areas $(0.2$ to $42.4,0.7$ to $8.6,10.7$ to $430.2,5.8$ to $49.8,2.1$ to $122.8,37.4$ to 359.4 and 0.2 to $11.4 \mathrm{mg} \mathrm{kg}^{-1}$ respectively). The surrounding available waters also carried high contents of $\mathrm{Cd}, \mathrm{Cu}, \mathrm{Pb}$ and $\mathrm{Zn}$, generally exceeding the fresh water acute and chronic criteria. Each mine site was ranked according to the Integrated Pollution Index (IPI). The normalized pollution index $\left(\mathrm{PI}^{\mathrm{n}}\right)$ for water and soil, and the Survey Index (SI) were used to determine IPI. The highest polluted mine site exhibited an IPI value of 0.6394. IPI was introduced to prioritize the research sites for further precise investigation.
\end{abstract}

Key Words: Mine pollution, Integrated pollution index (IPI), Normalized pollution index $\left(\mathrm{PI}^{\mathrm{n}}\right)$, Survey index (SI), Fresh water acute and Chronic criteria.

\section{INTRODUCTION}

Mine waste material containing sulphide waste is a major threat to the environment. Small quantities of metals occurring in the mined ores are not totally recovered by mill or processing operations, to be left in the tailing deposits. Such mining waste, containing significant metal concentrations, is a source of chemical pollution that may persist for a long time [1]. Mining and milling operations, together with grinding, concentrating ores and disposal of tailings, provide obvious sources of contamination in the surface environment, along with mine and mill wastewater [2]. Many studies have been conducted on heavy metal contamination in soils, plants, waters and sediments from metalliferous mines throughout the world [3-6]. The extent and degree of heavy metal contamination around the mines vary depending upon geochemical characteristics and mineralization of tailings. For example, tailings containing large quantities of sulfide minerals could influence nearby agricultural lands and streams.

*Address correspondence to this author at the Department of Environmental Engineering, Chungju National University, Daehak-ro 72, Chungju-si, Chungbuk, 380-702, Korea; Tel: +82438415357; Fax: +82438415350;

E-mail: hlee@cjnu.ac.kr
In Korea, various mines were distributed all over the country and were actively mined until the early 1980s. However, in the last two decades, most of these mines were closed due to economic reasons. After mine closure, mine waste materials, including tailings, were left without full environmental treatment. Thus, soils, plants, waters and sediments in the vicinity of the mines have been contaminated by potentially toxic elements from tailings by clastic movement through wind and water.

The objective of this study was to assess the soil and water contamination in the vicinity of 44 abandoned mines distributed in the South Han-river watershed areas, by using the Integrated Pollution Index (IPI). The study purpose was to detect the most highly contaminated mine areas and thereby assist efforts to protect the river watershed.

\section{MATERIALS AND METHODS}

To investigate the impact caused by the abandoned mine sites, soil (top and/or, sub, 396 samples) and water (stream and/or, ground, 128 samples) samples were collected from the target mine sites. From each mine site 9 samples were collected from different locations around the mine, like the mine's front $(0 \mathrm{~m})$ and control area, and at $200 \mathrm{~m}, 400 \mathrm{~m}$, $600 \mathrm{~m}, 800 \mathrm{~m}$ and $1600 \mathrm{~m}$ from the front. Sub soils were col- 


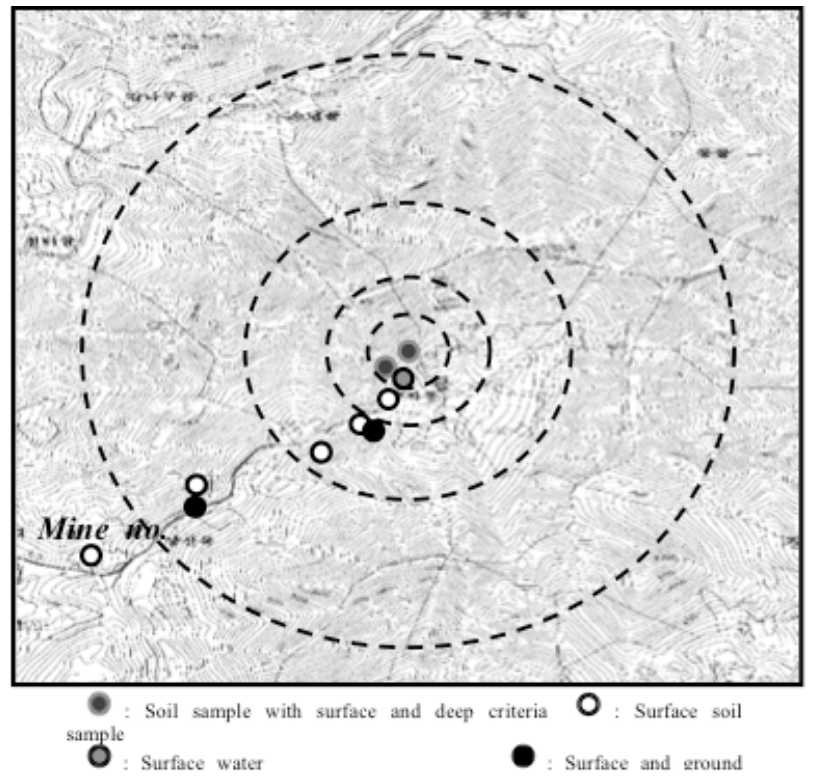

Fig. (1). Water and soil sampling location around mine no. 24 (no scale).

lected only from $0 \mathrm{~m}$ and $200 \mathrm{~m}$, while top soils were collected from all the distances. Each soil sample comprised a composite of 4 sub samples taken from an area of 1 sq-m. Soil samples were air dried in room temperature for 2-3 weeks until a constant weight was attained. Samples were disaggregated and passed through $2.0 \mathrm{~mm}$ and $250 \mu \mathrm{m}$ sieves. Following the Korean standard method [7], the sieved samples $(<2.0 \mathrm{~mm})$ were mixed with a 1:5 ratio of soil to $0.1 \mathrm{~N}$ $\mathrm{HCl}$ solution in a falcon tube (volume of $50 \mathrm{ml}$ ). For the final mixing, the solutions were shaken with the falcon tubes placed horizontally in a shaking machine at $185 \mathrm{rpm}$ for $1 \mathrm{hr}$ and then filtered through a $0.45 \mu \mathrm{m}$ Millipore membrane filter using a hand pump.

Aqua regia solution can extract between 70 to $90 \%$ of the total contents of trace elements [8]. A fine grained (< $250 \mu \mathrm{m})$ fraction of soil $(3 \mathrm{~g})$ was added to $28 \mathrm{ml}$ of aqua regia (1:3 of $\left.\mathrm{HNO}_{3}: \mathrm{HCl}\right)$, heated to $70^{\circ} \mathrm{C}$ for $1 \mathrm{hr}$ [8], filtered and diluted as specified. The filtered aqueous samples were used to detect heavy metals [arsenic (As), cadmium (Cd), copper $(\mathrm{Cu})$, nickel $(\mathrm{Ni})$, lead $(\mathrm{Pb})$ and zinc $(\mathrm{Zn})]$ using Inductively Coupled Plasma - Atomic Emission Spectrometry (ICPAES). A mercury analyzer was used to detect mercury ( $\mathrm{Hg})$ and the samples were sent to the Chungju Water Management Company for the detection of cyanide $\left(\mathrm{CN}^{-}\right)$and hexavalent chromium $\left(\mathrm{Cr}^{6+}\right)$. The $\mathrm{pH}$ of the soil was determined by the 1:5 ratio of soil to de-ionized water.

In addition, 128 stream water samples were collected from inside of the mines / mine front $/ 100 \mathrm{~m} / 200 \mathrm{~m} / 400 \mathrm{~m} /$ $600 \mathrm{~m} / 800 \mathrm{~m} / 1600 \mathrm{~m}$. Three water samples were collected from different locations at most of the mine areas. No water was sampled at two sites due to the absence of any surface water within $2 \mathrm{~km}$ of the mine. In Fig. (1), the criteria of sampling are shown.

\subsection{Method of IPI Estimation}

IPI was calculated from a weighted ratio of site survey, soil pollution index (PIs) and water pollution index (PIw).
According to the importance of the water, soil and survey, $50 \%, 30 \%$ and $20 \%$ values were used, respectively. The IPI ranged from 0 to 1 .

$$
\mathrm{IPI}=\alpha \mathrm{PIw}^{\mathrm{n}}+\beta \mathrm{PIs}^{\mathrm{n}}+\gamma \mathrm{SI}
$$

where, $\alpha, \beta$ and $\gamma$ are constants with following values.

$\alpha=0.5$ for the presence of water and 0 for the absence of water,

$\beta=0.3$ for the presence of water and 0.8 for the absence of water

$\gamma=0.2$

$\mathrm{PIw}^{\mathrm{n}}=$ Normalized Pollution Index of Water $\left(0 \leq \mathrm{PIw}^{\mathrm{n}} \leq 1\right)$

PIs $^{\mathrm{n}}=$ Normalized Pollution Index of Soil $\left(0 \leq \mathrm{PIs}^{\mathrm{n}} \leq 1\right)$

SI $=$ Survey Index

\subsection{Method of $\mathbf{P I}^{\mathrm{n}}$ Estimation}

$\mathrm{PI}^{\mathrm{n}}$ is the amount of the pollution normalized to the highest Pollution Index (PI). This relation is common for both water and soil samples. Simply,

$$
\mathrm{PI}^{2}=\frac{\text { Each mine site's }}{\text { Highest PI }}
$$

This PI was used in this study to evaluate the degree of trace metal contamination [9-12]. The tolerable level is the element concentration in the soil that supports crop production considered safe for human consumption $[13,14]$. The tolerable levels for soil and water are shown in Table $\mathbf{1}$ and Table 2 respectively.

$$
\text { PIs }=\frac{\sum \frac{\text { Heavy metal concentration in soil }}{\text { Tolerable Level }}}{\text { Number of heavy }}
$$

Table 1. Tolerable Level for Soil*

\begin{tabular}{|c|c|}
\hline Heavy Metals & Tolerable Level $\left(\mathbf{m g ~ k g}^{-\mathbf{1}}\right)$ \\
\hline \hline Cadmium $(\mathrm{Cd})$ & 1.5 \\
\hline Lead $(\mathrm{Pb})$ & 100 \\
\hline Nickel $(\mathrm{Ni})$ & 40 \\
\hline Zinc $(\mathrm{Zn})$ & 300 \\
\hline Copper $(\mathrm{Cu})$ & 50 \\
\hline Arsenic $(\mathrm{As})$ & 6 \\
\hline Mercury $(\mathrm{Hg})$ & 4 \\
\hline Hexavalent Chromium $\left(\mathrm{Cr}^{6+}\right)$ & 4 \\
\hline Cyanide $(\mathrm{CN})$ & 2 \\
\hline
\end{tabular}

* NIER and HERC, 2007.

Similarly, for the water samples, PIw was measured to evaluate the contamination of water as specified in the Korean standard.

$$
\mathrm{Plw}=\frac{\sum \frac{\text { Heavy metal concentration in water }}{\text { Tolerable Level }}}{\text { Number of heavy }}
$$


Table 2. Tolerable Level for Water*

\begin{tabular}{|c|c|}
\hline Heavy Metals & Tolerable Level $\left(\mathbf{m g ~ L}^{-\mathbf{1}}\right)$ \\
\hline \hline Cadmium $(\mathrm{Cd})$ & 0.005 \\
\hline Lead $(\mathrm{Pb})$ & 0.05 \\
\hline Arsenic $(\mathrm{As})$ & 0.05 \\
\hline Mercury $(\mathrm{Hg})$ & $0(<0.001)$ \\
\hline Hexavalent Chromium $\left(\mathrm{Cr}^{6+}\right)$ & 0.05 \\
\hline Cyanide $\left(\mathrm{CN}^{-}\right)$ & $0(<0.01)$ \\
\hline
\end{tabular}

*NIER and HERC, 2007.

\subsection{Method of SI Estimation}

SI indicates the evaluation of each mine site according to the following listed survey pattern. Ten evaluation items, as shown in Table $\mathbf{3}$, were selected for the mine area survey. The sulphuration and chlorosis indicate the change of the color of the soil, stone and plants within the mine area, compared to the nearby area. The value of SI ranges from 0 to 1.

$$
\mathrm{SI}=\frac{\sum \text { Score of evaluated }}{10}
$$

Table 3. Survey Criteria with Score*

\begin{tabular}{|c|c|c|}
\hline Evaluation Item & Criteria & Score \\
\hline 1. Overflow of water from mine & Yes / No & $1 / 0$ \\
\hline 2. $\mathrm{pH}$ of mine inside water & $<5.0 />5.0$ & $1 / 0$ \\
\hline 3. $\mathrm{pH}$ of soil & $<5.0 />5.0$ & $1 / 0$ \\
\hline 4. Existence of debris & Yes / No & $1 / 0$ \\
\hline 5. Debris position & \multirow{2}{*}{ Slope / Flat } & \multirow{2}{*}{$1 / 0$} \\
\hline (Slope criteria) & & \\
\hline 6. Peoples affected by mine & Yes / No & $1 / 0$ \\
\hline 7. Damage prevention facility & Yes / No & $0 / 1$ \\
\hline 8. Sulphuration and & \multirow{2}{*}{ Have / Haven't } & \multirow{2}{*}{$1 / 0$} \\
\hline Chlorosis phenomena & & \\
\hline 9. Plants around mine & Many / Few & $0 / 1$ \\
\hline 10. Inflow of stream & \multirow{2}{*}{ Yes / No } & \multirow{2}{*}{$1 / 0$} \\
\hline water to the mine & & \\
\hline
\end{tabular}

*NIER and HERC, 2007.

\section{RESULT AND DISCUSSION}

\subsection{Pollution Index of Soil (PIs)}

The plots of the mean and median values of trace element concentration from the $0.1 \mathrm{~N} \mathrm{HCl}$-treated soil samples are shown in Fig. (2). The logarithmic trend line of mean values remained mostly above the trend line for the median values. The sites with a median concentration above the mean value
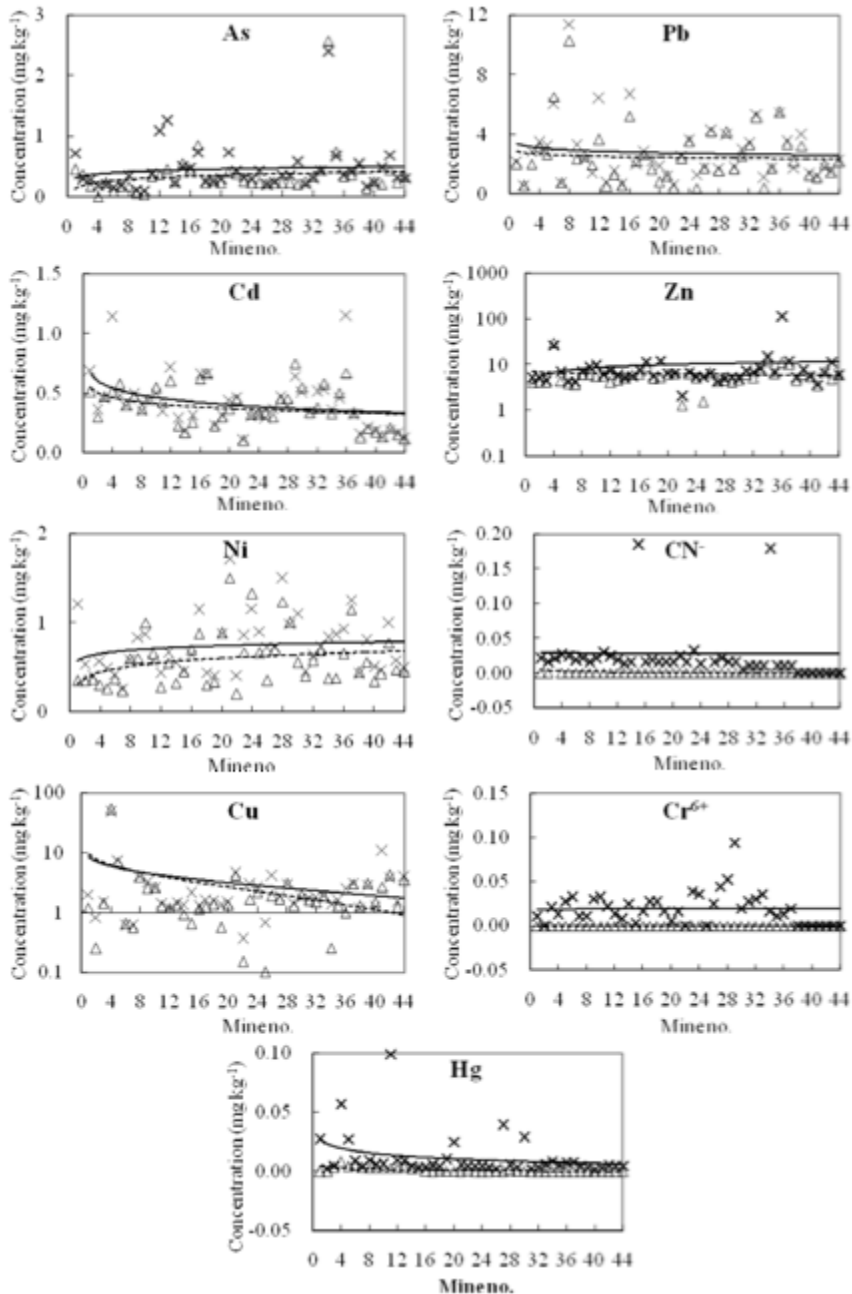

Fig. (2). Plots of the mean $(\times)$ and median $(\Delta)$ values of the soil contamination of $0.1 \mathrm{~N} \mathrm{HCl}$ treated soil samples with logarithmic line of mean (-) and median (---).

indicated that among the sampling points, the metal concentration at one or two points was very high with respect to the other points. Individually, the PIs varied from 0.0174 to 0.5556. After that, the mean PIs value of each mine site was determined. The maximum and minimum mean PIs values were 0.2127 and 0.0174 in site no. 4 and site no. 22 respectively.

Practically, the PI of aqua regia-treated soils was greater than that of $0.1 \mathrm{~N} \mathrm{HCl}$-treated soils. Among all sites, the mean PIs varied from 0.2117 to 2.0682 . Moreover, PIs at 8 sites was higher than 1 , which indicated highly contaminated soil according to PIs. Fig. (3) shows the maximum and minimum trace element concentrations of all sites. In the control area of most of the mines, the metal concentrations of $\mathrm{Cd}, \mathrm{Cu}, \mathrm{Pb}$ and $\mathrm{Zn}$ were higher than the world average of $0.35,30,35$ and $90 \mathrm{mg} \mathrm{kg}^{-1}$ respectively [15].

\subsection{Pollution Index of Water (PIw)}

Water has vast importance in IPI evaluation. The PIw among all sites varied from 0 , in mine no. 7 and no. 38 , to 0.4 in mine no. 42. The concentrations of $\mathrm{Cd}, \mathrm{As}, \mathrm{Hg} \mathrm{CN}^{-}$ and $\mathrm{Cr}^{6+}$ in most of the water samples were less than the given tolerable level. PIw was below 0.1 at $16(36.4 \%)$ of the 

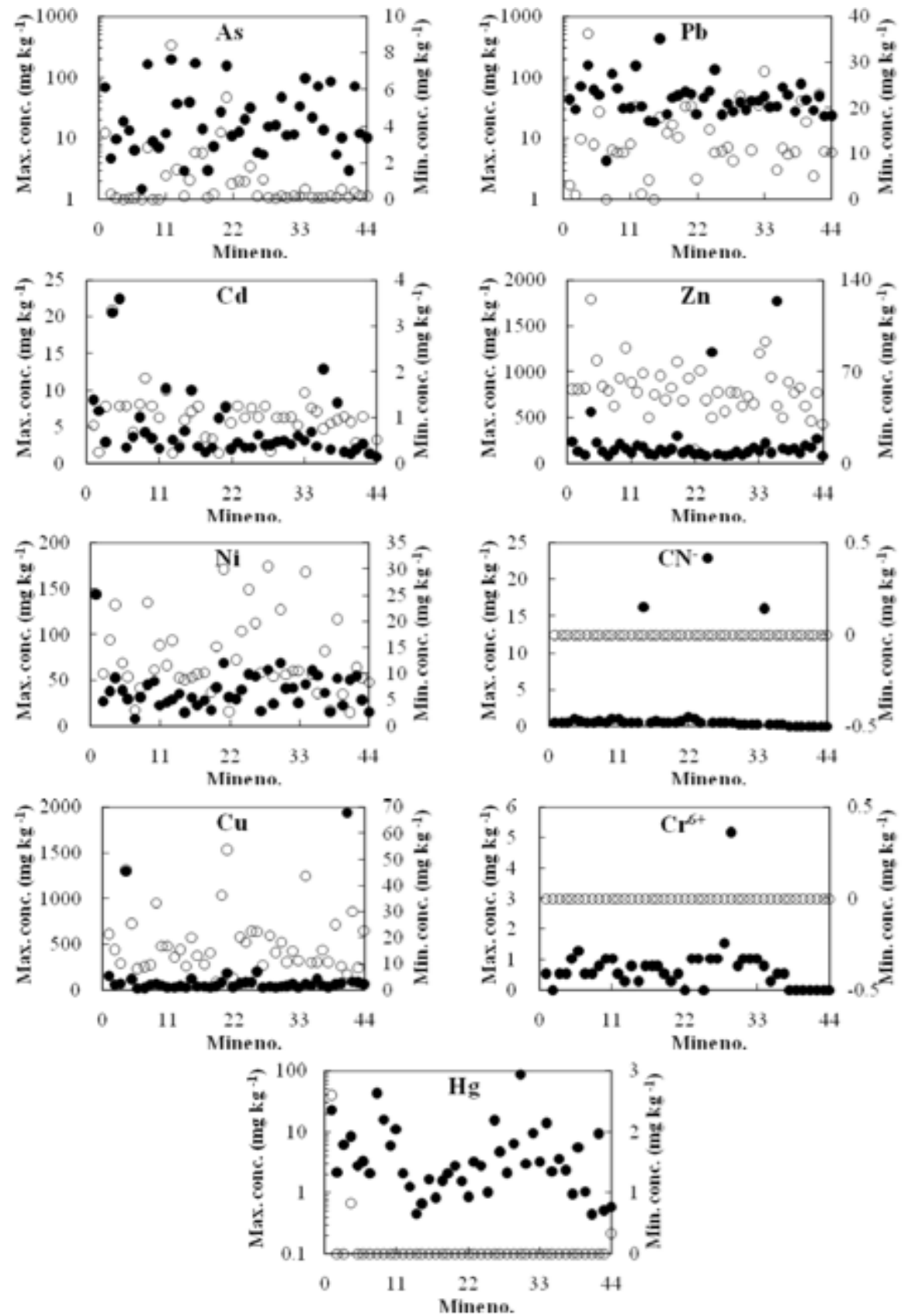

Fig. (3). Scattered plots of the aqua regia treated samples with the maximum (•) and minimum (o) concentrations of experimented trace metals for 44 mine sites.

sites, between 0.1 to 0.3 at $27(61.4 \%)$, and greater than 0.4 at $1(2.2 \%)$. The concentration of $\mathrm{Hg}, \mathrm{CN}^{-}$and $\mathrm{Cr}^{6+}$ remained below detection at all sites. Fig. (4) shows the bar charts of the heavy metal concentrations of the water samples with arithmetic mean and standard deviation, which were used to understand the water contamination range of the mine sites.

\subsection{Fresh Water Acute and Chronic Criteria}

The water around most of the mine areas exceeded the acute and chronic effect levels proposed by the US Environmental Protection Agency (USEPA) in 2007 [16]. Fig. (5) shows the heavy metal concentrations at the top five ranked sites, which exceeded the fresh water aquatic life acute and chronic criteria. The tolerable acute and chronic levels for fresh water are 340 and $150 \mu \mathrm{g} / 1$ for As, 2 and $0.25 \mu \mathrm{g} / 1$ for $\mathrm{Cd}, 13$ and $9 \mu \mathrm{g} / 1$ for $\mathrm{Cu}, 65$ and $2.5 \mu \mathrm{g} / 1$ for $\mathrm{Pb}$ and $120 \mu \mathrm{g} / 1$ for both for $\mathrm{Zn}$. Among all the studied areas, 95.5\% of the mine areas' water exceeded the acute and chronic limit of $\mathrm{Cd}$, while $91 \%$ of the sites exceeded the chronic limit of $\mathrm{Pb}$. However, the acute limit for $\mathrm{Pb}$ was exceeded in only two mine areas. The acute concentration for $\mathrm{Zn}$ was surpassed in $6.82 \%$ of the mine areas.

\subsection{Survey Index}

The survey index was measured at each site and the highest score of 6 was obtained by mine no. 4 , indicating the highest risk. Half of the 44 sites had a survey score above 1 and the other $50 \%$ had a survey index of 0.1 , which indicated 

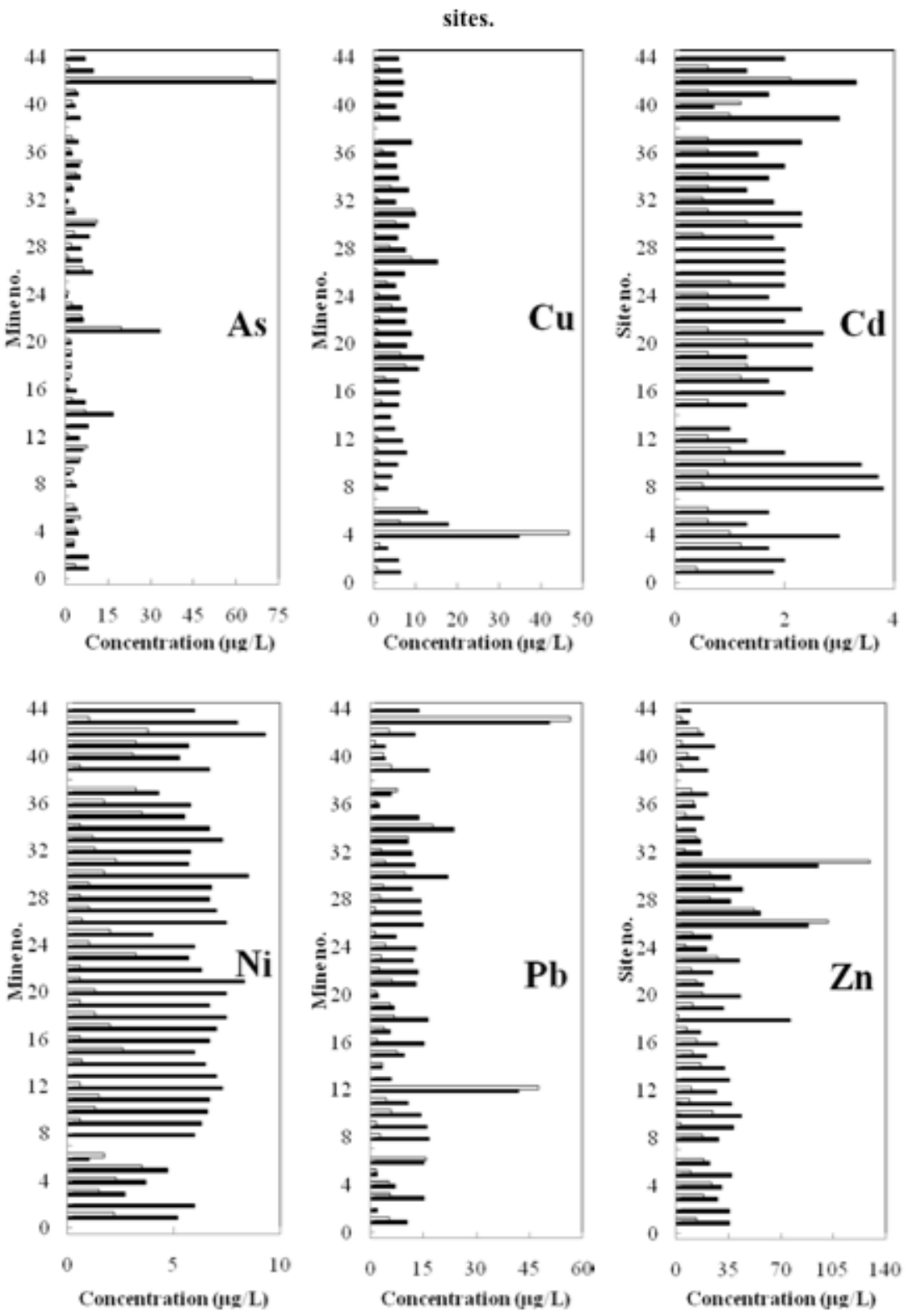

Fig. (4). Bar charts of heavy metal concentration with Arithmetic Mean

) and Standard Deviation ( $\square$ ) of the mine water samples.

that the surrounding areas were physically and visually less affected by the mine. Table 4 shows the survey index values.

\subsection{Integrated Pollution index (IPI)}

The values of $\mathrm{PIs}^{\mathrm{n}}$, PIw ${ }^{\mathrm{n}}$, SI and IPI for the top five ranked sites are shown in Table 4. The values of $\alpha=0$ and $\beta=0.8$ were only used in the two mine areas that suffered an absence of water. The PIs values from the aqua regia-treated soils were 5- to 25 -fold greater than that of $0.1 \mathrm{~N} \mathrm{HCl}$-treated soils. PIs $>1$ indicated the degree of importance. All $0.1 \mathrm{~N}$ $\mathrm{HCl}$-treated PIs were below 1, indicating low pollution criteria. However, this problem was successfully solved by IPI. The IPI ranking for both $0.1 \mathrm{~N} \mathrm{HCl}$ - and aqua regia-treated samples showed similar values. The top five ranked sites were nearly the same for both treated systems. IPI normalized the PIs values by comparing them with the maximum value. Moreover, SI showed the importance of justifying the pollution index. For the $0.1 \mathrm{~N}$ HCl-treated samples, only 8 mine areas had an IPI value below 0.2. However, two mines had an IPI value over 0.5. Similarly, for the aqua regiatreated samples, the IPI values ranged from 0.1185 to 0.6394. In common, the top five ranked mine areas were significantly affected by trace metals in the soils and water. Importantly, various contamination index such as index for chemistry of the sediment quality triad component (I), marine sediment pollution index (MSPI) [17], enrichment index (EI) [18], combined pollution index (CPI) [19]; ecological risk index such as the mean sediment quality guideline quotient (SQG-Q) [20], and mean sediment quality guideline quotient as an indicator of contamination and acute toxicity (SQG-QI) [21-22], all have an averaging nature capable of aggregating all contaminants into one value. Similarly, IPI has the same property to aggregate all contaminants into one value. IPI is therefore a superior method to prioritize the 

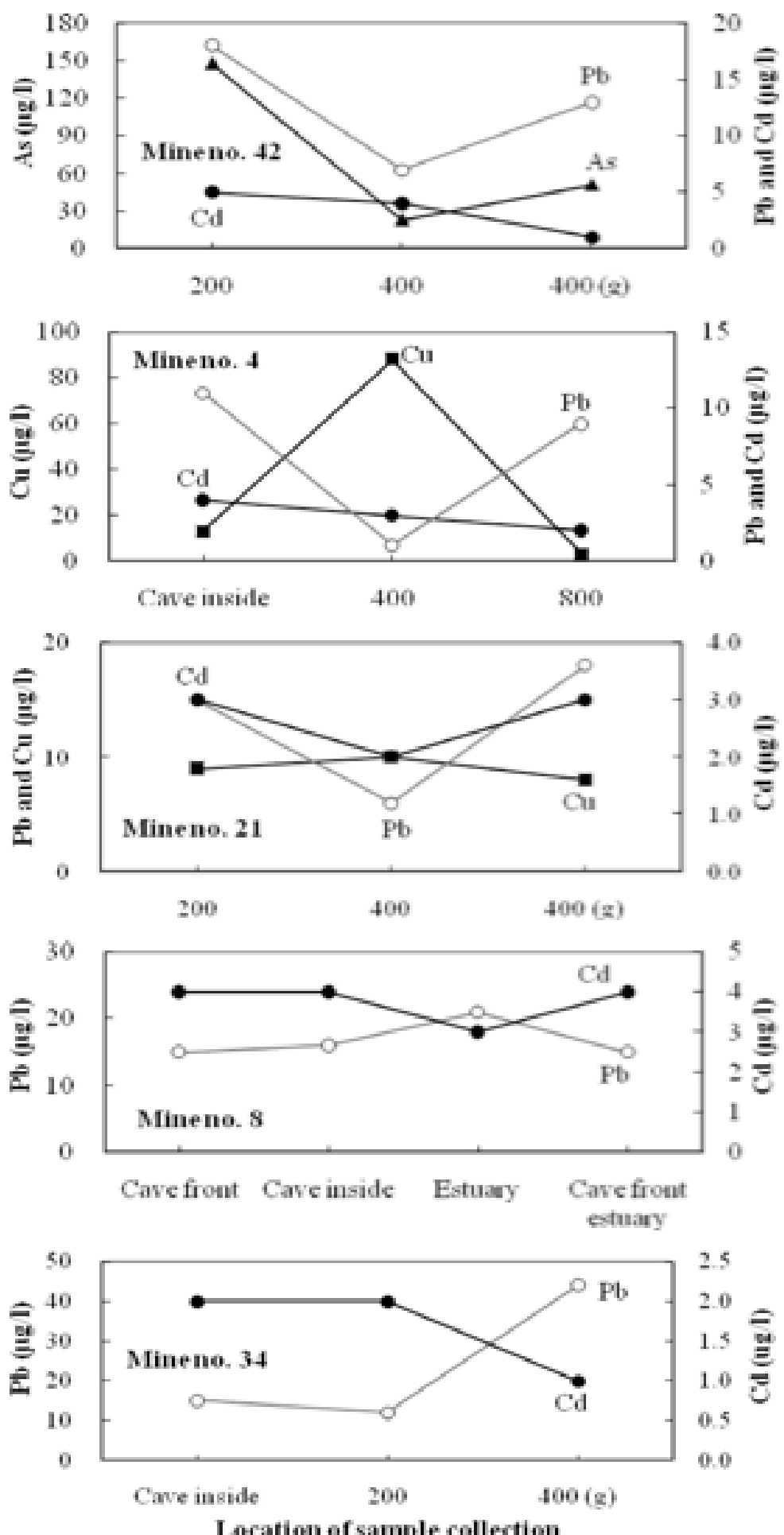

Fig. (5). Plots of the exceeded limits of fresh water criteria including ground water ( $\mathrm{g}$ ) at various distances (mostly in meter) for the top 5 ranked mine sites.

comparison of site contamination. IPI is only applicable on a group of sites to determine the contamination from higher to lower values among those sites.

\section{CONCLUSION}

Both soil and water in all of the mine areas were contaminated by past mining activity. The mean PIs values of the 44 mines were determined and site no. 4 and no. 22 had maximum and minimum values of 0.2127 and 0.0174 , respectively, according to the Korean standard method. The concentrations of $\mathrm{Cd}, \mathrm{As}, \mathrm{Hg}, \mathrm{CN}^{-}$and $\mathrm{Cr}^{6+}$ were lower than the tolerable levels for most of the water samples. The concentrations of $\mathrm{Hg}, \mathrm{CN}^{-}$and $\mathrm{Cr}^{6+}$ were below detectable limits in all the sites' water samples. PIw was below 0.1 at 16 (36.4\%) of the sites, between 0.1 to 0.3 at $27(61.4 \%)$, and greater than 0.4 at $1(2.2 \%)$. Among the 44 mines, the top 
Table 4. Values of 5 Top Most IPI with Ranking for Different Extraction Methods

\begin{tabular}{|c|c|c|c|c|c|c|c|c|c|c|c|}
\hline \multirow[t]{2}{*}{ Mine no. } & \multicolumn{2}{|c|}{$\begin{array}{c}\text { 0.1N HCl Treated } \\
\text { Soil }\end{array}$} & \multicolumn{2}{|c|}{$\begin{array}{c}\text { Aquaregia Treated } \\
\text { Soil }\end{array}$} & \multicolumn{2}{|c|}{ Water } & \multicolumn{2}{|c|}{$\begin{array}{c}\text { 0.1N HCl Treated } \\
\text { Soil }\end{array}$} & \multicolumn{2}{|c|}{$\begin{array}{c}\text { Aquaregia Treated } \\
\text { Soil }\end{array}$} & \multirow{2}{*}{$\begin{array}{c}\text { Survey } \\
\text { SI }\end{array}$} \\
\hline & IPI & Rank & IPI & Rank & PIw & $\mathbf{P I}^{\mathrm{n}}$ & PIs & $\mathbf{P I s}^{\mathrm{n}}$ & PIs & $\mathbf{P I s}^{\mathrm{n}}$ & \\
\hline 42 & 0.5705 & 2 & 0.6394 & 1 & 0.4000 & 1.0000 & 0.0358 & 0.1683 & 0.8231 & 0.3980 & 0.1000 \\
\hline 4 & 0.5936 & 1 & 0.5936 & 2 & 0.1389 & 0.3472 & 0.2127 & 1.0000 & 2.0682 & 1.0000 & 0.6000 \\
\hline 21 & 0.4722 & 3 & 0.5698 & 3 & 0.2433 & 0.6083 & 0.0624 & 0.2933 & 1.2796 & 0.6187 & 0.4000 \\
\hline 8 & 0.4020 & 4 & 0.4978 & 4 & 0.1933 & 0.4833 & 0.0570 & 0.2678 & 1.2146 & 0.5873 & 0.4000 \\
\hline 34 & 0.3971 & 5 & 0.4432 & 5 & 0.1522 & 0.3806 & 0.0899 & 0.4228 & 1.1922 & 0.5764 & 0.4000 \\
\hline Maximum & 0.5936 & --- & 0.6394 & & 0.4000 & --- & 0.2127 & --- & 2.0682 & --- & 0.6000 \\
\hline
\end{tabular}

five ranked mine areas were significantly contaminated with heavy metals. The maximum and minimum IPI values were 0.6394 and 0.1185 , respectively. According to the SI survey, none of the mines had any damage prevention facility, indicating a high risk of contamination. A comprehensive program should be developed to promote measures that best fit the rehabilitation of the environmentally affected sites. Site selection preference should be followed by the IPI ranking.

\section{ACKNOWLEDGEMENT}

This research was assisted by the financial support of the Fundamental Investigation on Environment of the Han River.

\section{APPENDIX}

All relevant data tables are available from "Environmental Water Quality Lab., Department of Environmental Engineering, Chungju National University, Daehak-ro 72, Chungju-si, Chungcheongbuk-do, 380-702, Korea."

\section{REFERENCES}

[1] Marcus JJ. Mining Environmental Handbook, Imperial College Press: London 1997; p. 785.

[2] Adriano DC. Trace Elements in the Terrestrial Environment. Springer Verlag: New York 1986

[3] Thornton I. Geochemical Aspects of Heavy Metal Pollution and Agriculture in England and Wales. In Inorganic Pollution and Agriculture, MAFF ref. Book, HMSO: London 1980; p. 326

[4] Fuge R, Paveley CF, Holdham MT. Heavy metal contamination in the Tanat Valley, North Wales. Environ Geochem Health 1989; 11: 127.

[5] Merrington G, Alloway BJ. The transfer and fate of $\mathrm{Cd}, \mathrm{Cu}, \mathrm{Pb}$ and $\mathrm{Zn}$ from historic metalliferous mine sites in the UK. Appl Geochem 1994; 9: 677.

[6] Jung MC. Heavy metal contamination of soils, plants, waters and sediments in the vicinity of metalliferous mines in korea. Unpublished $\mathrm{PhD}$ thesis, University of London 1995.

[7] Jung MC. Heavy metal contamination of soils and waters in and around the Imcheon Au-Ag mine, Korea. Appl Geochem 2001; 16(11-12): 1369 .
[8] Ure AM. Methods of Analysis for Heavy Metals in Soils. In: Alloway BJ, Ed. Heavy Metals in Soils. Blackie: London 1990.

[9] NIER. Investigation of the impact of mine discharge on Han-river watershed. $1^{\text {st }}$ year's report 2007.

[10] Nishida H, Miyai M, Tada F, Suzuki S. Computation of the index of pollution caused by heavy metals in river sediment. Environ Pollut Ser 1982; B4: 241.

[11] Chon HT, Ahn JS, Jung MC. Environmental Contamination of Toxic Heavy Metals in the Vicinity of Some Au-Ag Mines in Korea. Proc. of the $4^{\text {th }}$ Biennial SGA Meeting, Truku: Finland 1991; p. 891.

[12] Kim KW, Lee HK, Yoo BC. The environmental impact of gold mines in the Yugu-Kwangcheon Au-Ag metallogenic province, Republic of Korea. Environ Tech 1998; 19: 291.

[13] Lee JS, Chon HT, Kim JS, Kim KW, Moon HS. Enrichment of potentially toxic elements in areas underlain by black shales and slates in Korea. Environ Geochem Health 1998; 20: 135.

[14] Kloke A. Content of Arsenic, Cadmium, Chromium, Fluorite, Lead, Mercury, and Nickel in Plants Grown on Contaminated Soil Paper presented at United Nations ECE Symp 1979.

[15] Reiman C, Caritat P. Chemical Elements in the Environment. Fact Sheets for the Geochemist and Environmental Scientist. Springer Verlag: Berlin 1998.

[16] Bowen HJM. Environmental Chemistry of the Elements. Academic Press: New York 1979

[17] USEPA. Recent recommended water quality criteria. 2007, Available from:http://www.epa.gov/waterscience/criteria/wqcriteria.html

[18] Shin PKS, Lam WKC. Development of a marine sediment pollution index. Environ Pollut 2001; 113: 281

[19] Ferreira Da Silva E, Cardoso Fonseca E, Matos JX, Patinha C, Reis $\mathrm{P}$, Santos Oliveira JM. The effect of unconfined mine tailings on the geochemistry of soils, sediments and surface waters of the Lousal area (Iberian pyrite belt, Southern Portugal). Land Degrad Dev 2005; 16: 213

[20] Zhou JM, Dang Z, Cai MF, Liu CQ. Soil heavy metal pollution around the Dabaoshan mine, Guangdong province: China. Pedosphere 2007; 17: 588 .

[21] Long ER, Macdonald DD. Recommended uses of empirically derived, sediment quality guidelines for marine and estuarine ecosystems. Hum Ecol Risk Assess 1998; 4: 1019.

[22] Fairey R, Long ER, Roberts CA, et al. An evaluation of methods for calculating mean sediment quality guideline quotients as indicators of contamination and acute toxicity to amphipods by chemical mixture. Environ Toxicol Chem 2001; 20: 2276.

(C) Hosik et al.; Licensee Bentham Open.

This is an open access article licensed under the terms of the Creative Commons Attribution Non-Commercial License (http://creativecommons.org/licenses/by-nc/3.0/) which permits unrestricted, non-commercial use, distribution and reproduction in any medium, provided the work is properly cited. 